\title{
A Simple Purification Procedure for and Further Characterization of a Glucodextranase* from Arthrobacter globiformis $\mathrm{I}_{4}{ }^{\dagger}$
}

\author{
Gentaro OKada, Takehiro UnNo and Teruo SAWAi** \\ Department of Biology, Faculty of Education, \\ Shizuoka University, Shizuoka 422, Japan \\ Received February 29, 1988
}

\begin{abstract}
A highly purified glucodextranase (EC 3.2.1.70) was simply prepared from cell-free culture broth of Arthrobacter globiformis 142 by ammonium sulfate fractionation, affinity chromatography on Sephadex G-100 and column chromatography on DEAE-cellulose. The purified enzyme was judged to be essentially homogeneous on PAGE and SDS-PAGE as well as isoelectric focusing. $E_{1 \mathrm{~cm}}^{\mathrm{I} \%}$ at $280 \mathrm{~nm}$ was 18.6 . The enzyme is an acidic protein with a $\mathrm{p} I$ of 4.31 . The molecular weight of the enzyme was estimated to be about 120,000 by SDS-PAGE. The enzyme is rich in alanine and glycine. No carbohydrate moiety seemed to be associated with the enzyme protein.

The optimum pH and temperature of the enzyme are $\mathrm{pH} 6.0$ and $45^{\circ} \mathrm{C}$, respectively. The enzyme was completely stable over the pH range of $5.5 \sim 7.5$ at $4^{\circ} \mathrm{C}$ for $24 \mathrm{hr}$, and retained about $40 \%$ of its original activity after heating at $60^{\circ} \mathrm{C}$ for $10 \mathrm{~min}$. Inactivation of the enzyme was found to be partial with $5 \mathrm{~mm} \mathrm{~Pb}^{2+}$ or $\mathrm{Zn}^{2+}$, and complete with $5 \mathrm{~mm}$ each of $\mathrm{Cu}^{2+}, \mathrm{Hg}^{2+}, \mathrm{Fe}^{3+}, \mathrm{KMnO}_{4}$ and NBS. The enzyme split dextran or isomaltose to produce $\beta$-glucose, indicating that the $\alpha$ glycosidic linkages in these substrates are inverted. The $K m$ value of the enzyme for dextran is $0.014 \%$. Phenyl $\alpha$-D-glucoside is a potent competitive inhibitor $(K i=1.69 \mathrm{~mm})$.
\end{abstract}

In 1976, Sawai et al. ${ }^{1)}$ first reported that an exo-1,6- $\alpha$-glucosidase (1,6- $\alpha$-D-glucan glucohydrolase, EC 3.2.1.70) was produced extracellulary by a Gram-positive and pleomorphic soil bacterium identified as Arthrobacter globiformis strain I42. They described the partial purification and some catalytic properties of this enzyme. ${ }^{1{ }^{27}}$ The enzyme was characterized as a glucodextranase, because it released only $\beta$-glucose from the non-reducing ends of dextran molecules. ${ }^{1,2)}$ Later on the enzyme was obtained in a crystalline state by Ohya et al. ${ }^{3)}$

This paper describes an improved purification procedure for and further characterization of the glucodextranase from $\mathrm{A}$. globiformis $\mathrm{I} 42$.

\section{MATERIALS AND METHODS}

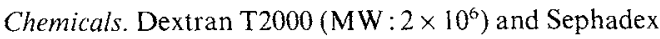
G-100 were products of Pharmacia Fine Chemicals, Uppsala, Sweden. DEAE-Cellulose $(0.85 \mathrm{meq} / \mathrm{g})$ was a product of The Brown Co., West Germany, crystalline bovine serum albumin from Miles Laboratories Inc., U.S.A., methyl $\alpha$-D-glucoside, used as an elution ligand, from Tokyo Kasei Kogyo Co., Ltd., Japan, methyl $\alpha$-Dglucoside, used for investigating the inhibition kinetics, from Wako Pure Chemical Industries, Ltd., Japan, phenyl $\alpha$-Dglucoside from Nakarai Chemicals, Ltd., Japan, isomaltose from Hayashibara Biochemical Laboratories, Inc., Japan, polypeptone from Daigo Eiyo Kagaku Co., Ltd., Japan, and carrier ampholyte ( $\mathrm{pH} 4 \sim 6)$ from LKB Produkter AB, Stockholm, Sweden. Standard proteins for SDS-PAGE (SDS-6H) were products of Sigma Chemical Company, St. Louis, U.S.A. Clinical dextran (Meito 70) was kindly supplied by Meito Sangyo Co., Ltd., Japan. All other reagents were of analytical grade.

$\dagger$ Studies on a Glucodextranase from Arthrobacter globiformis I42. Part I.

* Abbreviation used in this paper for exo-1,6- $\alpha$-glucosidase.

** An Emeritus Professor at Aichi Kyoiku University.

Abbreviations: PAGE, polyacrylamide gel electrophoresis; SDS, sodium dodecyl sulfate; NBS, N-bromosuccinimide; EDTA, disodium ethylenediaminetetraacetic acid; $p \mathrm{CMB}$, $p$-chloromercuribenzoate. 
Organism. The organism used for preparation of the glucodextranase was a Gram-positive soil bacterium, Arthrobacter globiformis I42 (NRRL B-4427, IAM 12102).

Cultures. The standard culture medium for enzyme production comprised 61 of a liquid medium containing $1.5 \%$ clinical dextran (Meito 70), 0.2\% $\mathrm{NH}_{4} \mathrm{NO}_{3}, 0.1 \%$ $\mathrm{KH}_{2} \mathrm{PO}_{4}, \quad 0.05 \% \quad \mathrm{MgSO}_{4} \cdot 7 \mathrm{H}_{2} \mathrm{O}, \quad 0.04 \% \quad \mathrm{CaCl}_{2} \cdot 2 \mathrm{H}_{2} \mathrm{O}$, $0.3 \%$ polypeptone, $0.3 \%$ meat extract and $0.1 \%$ asparagine. The medium was adjusted to $\mathrm{pH} 8.5$ by the addition of $1 \mathrm{~N} \mathrm{NaOH}$ and then sterilized in a Tokyo Rikakikai 11.5-l jar-fermentor (model M-200) at $120^{\circ} \mathrm{C}$ for $40 \mathrm{~min}$. The precultured broth $(200 \mathrm{ml})$ of $A$. globiformis I42 grown in the same medium for 2 days was inoculated into the standard culture medium, and then the cultivation was performed at $20^{\circ} \mathrm{C}$ for $65 \mathrm{hr}$ at an aeration rate of $3 \mathrm{l} / \mathrm{min}$ and a rotational speed of $50 \mathrm{rpm}$. The cell-free culture fluid was obtained using a Tomy Seiko continuous centrifuge (model RS-20 II, $10,000 \times g$ ) and then used as the starting material for enzyme purification.

Substrate and enzyme assay. Dextran T2000 was used as the substrate for the enzyme assay. Dextran-saccharifying activity was examined for the standard assay. The reaction mixture for the glucodextranase assay contained $0.25 \mathrm{ml}$ of $1 \%$ dextran T2000, $0.5 \mathrm{ml}$ of $40 \mathrm{~mm}$ acetate buffer ( $\mathrm{pH} 6.0$ ), containing $10 \mathrm{~mm}$ calcium acetate, and $0.25 \mathrm{ml}$ of the enzyme solution. The mixture was incubated at $30^{\circ} \mathrm{C}$ for an appropriate period. Glucose produced, in $0.5 \mathrm{ml}$ of the reaction mixture, was measured by the glucostat meth$\operatorname{od}^{4,5)}$ One unit of enzyme activity was defined as the amount of enzyme that catalyzed the liberation of $1.0 \mu \mathrm{mol}$ of D-glucose from the substrate per min under the above conditions.

Measurement of protein and carbohydrate. Protein concentrations were measured by the method of Lowry et al. ${ }^{\text {()) }}$ with crystalline bovine serum albumin as a standard. The absorbance at $280 \mathrm{~nm}$ was used for monitoring protein in column effluents.

The total carbohydrate in the purified enzyme was determined by the phenol-sulfuric acid method ${ }^{-1}$ with Dglucose as a standard.

Polyacrylamide gel electrophoresis. PAGE was performed in $7.5 \%$ polyacrylamide with Tris diethylbarbituric acid buffer ( $\mathrm{pH} 7.0$ ) according to the method of Davis. ${ }^{8)}$ SDS-PAGE was performed in $5 \%$ polyacrylamide containing $0.1 \%$ SDS by the method of Weber and Osborn. ${ }^{9)}$ In both cases, the gels were stained in $0.25 \%$ Coomassie Brilliant Blue R-250-50\% methanol $-10 \%$ acetic acid.

Isoelectric focusing. The $\mathrm{pI}$ of the enzyme was measured, using an LKB Ampholine electrofocusing apparatus $(110 \mathrm{ml})$, by the method of Vesterberg and Svensson. ${ }^{10)}$
Amino acid analysis. Amino acid analysis of the purified enzyme was performed with a Nihondenshi amino acid analyzer (model JLC-200A) or a Waters HPLC apparatus (model QA-1), under the conditions given under Results.

Column chromatography. To purify the enzyme, column chromatographies on Sephadex G-100 and DEAEcellulose were performed.

Polarimetric procedure. A $1.0 \mathrm{ml}$ sample of the buffered enzyme solution, $\mathrm{pH} 6.0$ (100 units), containing $5 \mathrm{~mm}$ calcium acetate was added to $4.0 \mathrm{ml}$ of a $3 \%$ isomaltose solution, followed by thorough mixing. Then a part of the resultant mixture was quickly transferred to a $0.1-\mathrm{dm}$ polarimeter cell and the changes in the rotation were measured at $30^{\circ} \mathrm{C}$ at intervals with a Union Gikken automatic digital polarimeter (model PM-101). After incubation for $15 \mathrm{~min}$. one drop of concentrated ammonium hydroxide was added to the polarimeter cell and then the rotation was again measured after thorough mixing.

Measurement of $\mathrm{Km}$ and $\mathrm{V}$ for dextran. A mixture of $0.5 \mathrm{ml}$ of a $0.01 \sim 0.25 \%$ dextran T2000 solution and $1.0 \mathrm{ml}$ of $40 \mathrm{~mm}$ acetate buffer, containing $10 \mathrm{~mm}$ calcium acetate ( $\mathrm{pH} 6.0$ ), with or without $10 \mathrm{~mm}$ phenyl $x$-D-glucoside or $20 \mathrm{~mm}$ methyl $\alpha-\mathrm{D}$-glucoside was equilibrated at $30^{\circ} \mathrm{C}$. The reaction was started by the addition of $0.5 \mathrm{ml}$ of the purified enzyme (0.044 units) warmed to the same temperature. After incubation for $10 \mathrm{~min}, 0.5-\mathrm{ml}$ samples were removed and the glucose liberated was measured by the glucostat method. The $K m$ and $V$ values were calculated from Lineweaver-Burk plots. ${ }^{11}$

\section{RESULTS}

Time courses of cell growth and glucodextranase production during the cultivation

Samples of about $20 \mathrm{ml}$ each of the culture medium in a jar-fermentor were taken at appropriate times, and the absorbance at $660 \mathrm{~nm}$ was immediately measured as cell growth. Each sample was subjected to centrifugation at $10,000 \times g$ at $4^{\circ} \mathrm{C}$ to remove bacterial cells. The glucodextranase activity, protein concentration and $\mathrm{pH}$ of each culture broth were then measured. The time courses of growth of the bacterium and the enzyme production are summarized in Fig. 1.

\section{Purification of glucodextranase}

Unless otherwise stated, all purification procedures for the enzyme were performed in a cold room $\left(4^{\circ} \mathrm{C}\right)$. 


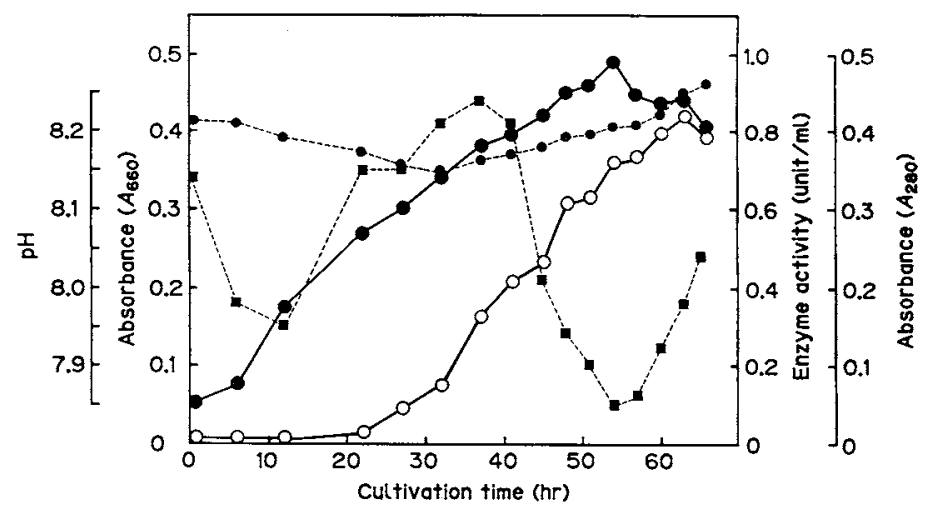

Fig. 1. Time Courses of Cell Growth and Glucodextranase Production.

-----, protein concentration $\left(A_{280 \mathrm{~nm}}\right) ;-\mathrm{O}-$, glucodextranase activity; - $\mathrm{pH}$. The experimental details are given in the text.

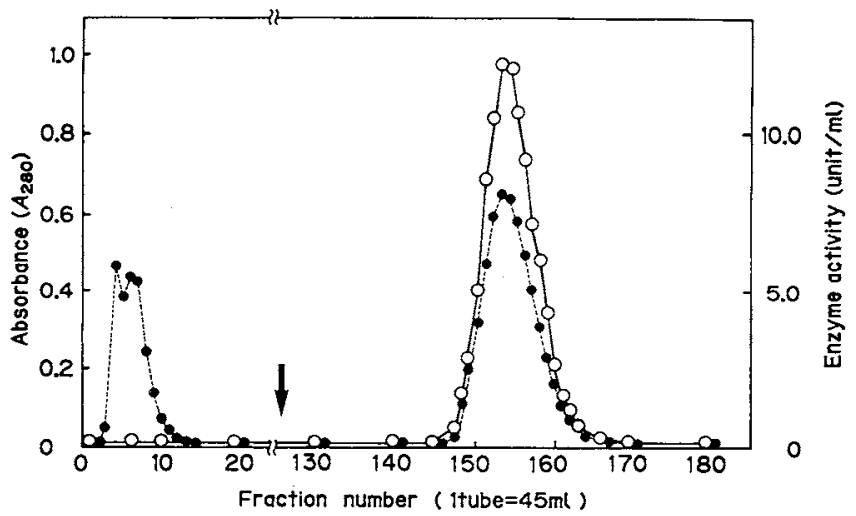

FIG. 2. Elution Patterns of the Crude Enzyme after $\left(\mathrm{NH}_{4}\right)_{2} \mathrm{SO}_{4}$ Fractionation on Affinity Chromatography on Sephadex G-100.

$5 \%$ Methyl $\alpha$-D-glucoside was added to the elution buffer at the position indicated by the arrow: --- ---, protein concentration $\left(A_{280 \mathrm{~nm}}\right) ;-\mathrm{O}-$, glucodextranase activity. The active fractions (tube Nos. 145 165) were combined.

Step 1. Ammonium sulfate fractionation. Solid ammonium sulfate was added to the cellfree culture broth ( $\mathrm{ca} .61$ ) to $90 \%$ saturation. After being kept overnight, the solution was subjected to continuous centrifugation at $10,000 \times \mathrm{g}$. The precipitates were dissolved in $230 \mathrm{ml}$ of $20 \mathrm{mM}$ acetate buffer containing $5 \mathrm{~mm}$ calcium acetate.

Step 2. Affinity chromatography on Sephadex $G-100$. The precipitate solution was applied on a column of Sephadex G-100 $(6.0 \times 42 \mathrm{~cm})$ preequilibrated with $20 \mathrm{~mm}$ acetate buffer containing $5 \mathrm{~mm}$ calcium acetate (pH 6.0). The glucodextranase protein was completely adsorbed onto Sephadex G-100 under the above conditions. After washing the column with $c a .5 .61$ of the buffer mentioned above, the enzyme was eluted with the same buffer containing $5 \%$ methyl $\alpha$-Dglucoside at a flow rate of $45 \mathrm{ml} / 60 \mathrm{~min} /$ tube. Fraction Nos. 145 to 166, which contained most of the glucodextranase activity (Fig. 2), were collected and then concentrated to about $8 \mathrm{ml}$ by ultrafiltration with a Diaflo YM-2 membrane (Amicon Corp., Lexington, Mass., U.S.A.) and a collodion bag (Sartorius $\mathrm{GmbH}$ ). The concentrated solution was dialyzed against the same buffer overnight. 


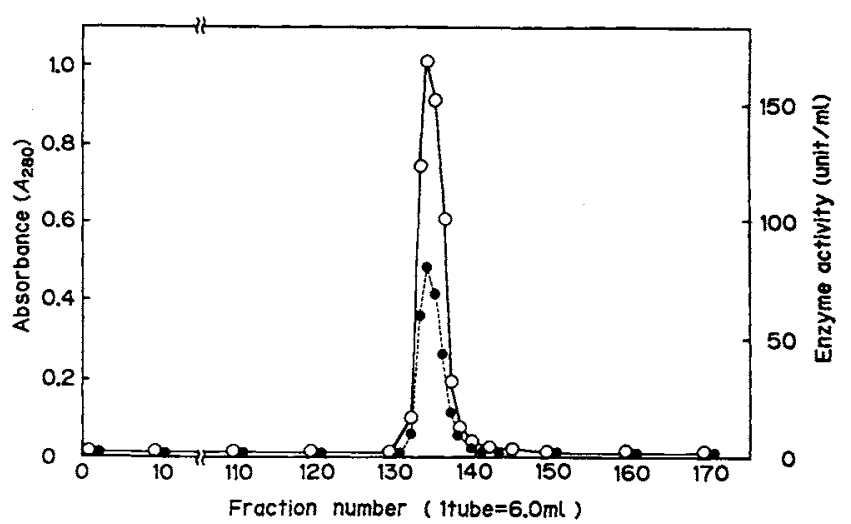

FIG. 3. DEAE-Cellulose Column Chromatography of the Enzyme after the Sephadex G-100 Column Chromatography.

----, protein concentration $\left(A_{280 \mathrm{~nm}}\right) ;-\mathrm{O}-$, glucodextranase activity. The active fractions (tube Nos. $131 \sim 140$ ) were combined.

Table I. Recoveries and Activities of the Enzyme during Purification

\begin{tabular}{|c|c|c|c|c|c|}
\hline \multirow[b]{2}{*}{ Purification step } & \multirow{2}{*}{$\begin{array}{l}\text { Total } \\
\text { volume } \\
\text { (ml) }\end{array}$} & \multirow{2}{*}{$\begin{array}{l}\text { Total } \\
\text { protein }^{a} \\
\text { (mg) }\end{array}$} & \multicolumn{2}{|c|}{ Enzyme activity } & \multirow{2}{*}{$\begin{array}{c}\text { Sp. activity } \\
\text { (units/mg } \\
\text { protein) }\end{array}$} \\
\hline & & & $\begin{array}{l}\text { Total } \\
\text { units }\end{array}$ & $\begin{array}{l}\text { Yield } \\
(\%)\end{array}$ & \\
\hline $\begin{array}{l}\text { 1. }\left(\mathrm{NH}_{4}\right)_{2} \mathrm{SO}_{4} \text { fraction } \\
(90 \% \text { saturation })\end{array}$ & 252 & 3500 & 5430 & 100 & 1.55 \\
\hline 2. Sephadex G-100 & 990 & 198 & 4400 & 81.0 & 22.2 \\
\hline 3. DEAE-Cellulose & 60 & 144 & 3680 & 67.8 & 25.6 \\
\hline
\end{tabular}

${ }^{a}$ Measured by the method of Lowry et al ${ }^{6}$ )

Step 3. DEAE-Cellulose column chromatography. The dialyzed sample was applied on a column of DEAE-cellulose $(2.2 \times 45 \mathrm{~cm})$ preequilibrated with $20 \mathrm{~mm}$ acetate buffer containing $5 \mathrm{~mm}$ calcium acetate ( $\mathrm{pH} 6.0$ ). After washing the column with ca. $600 \mathrm{ml}$ of the buffer mentioned above, the enzyme was eluted with the same buffer containing $0.3 \mathrm{M} \mathrm{NaCl}$ at a flow rate of $6.0 \mathrm{ml} / 20 \mathrm{~min} /$ tube. A symmetrical protein peak containing only glucodextranase activity was obtained (Fig. 3). The active fractions (tube Nos. $131 \sim 140$ ) were then combined.

Table I summarizes the overall purification steps. The purified enzyme had a specific activity of 25.6 units per $\mathrm{mg}$ of protein, the final yield being about $68 \%$, and it was used for the subsequent characterization.
Purity and molecular weight of the purified enzyme

The purified enzyme gave a single protein band on PAGE and SDS-PAGE (Fig. 4). $E_{1 \mathrm{~cm}}^{1 \%}$ at $280 \mathrm{~nm}$ was determined to be 18.6 from the absorbance and dry weight of the purified enzyme. No carbohydrate moiety associated with the enzyme protein was detected.

The molecular weight of the purified enzyme was found to be about 120,000 on comparison of its relative mobility on SDS-PAGE with those of standard proteins (SDS-6H).

\section{Isoelectric point}

The purified enzyme was subjected to isoelectric focusing to determine its $\mathrm{p} I$ and also to check its homogeneity. A sharp and symmetrical protein peak containing only glucodextranase activity was obtained, as can be 


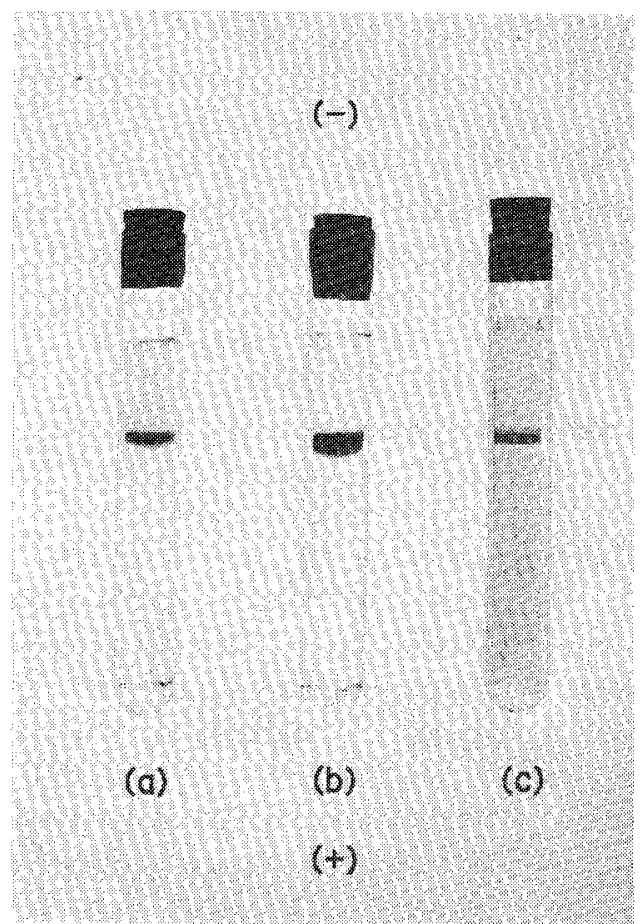

FIG. 4. Polyacrylamide Gel Electrophoresis of the Purified Glucodextranase.

Samples of the purified enzyme, $10 \mu \mathrm{g}$ (a) and $40 \mu \mathrm{g}$ (b), were applied on gel columns of $7.5 \%$ polyacrylamide and then run at $4^{\circ} \mathrm{C}$ at a constant current of $2 \mathrm{~mA}$ per gel column. (c) A sample of the purified enzyme $(10 \mu \mathrm{g})$ was applied on a gel column of $5 \%$ polyacrylamide containing $0.1 \% \mathrm{SDS}$, followed by electrophoresis at room temperature for $3.5 \mathrm{hr}$ at a constant current of $8 \mathrm{~mA}$ per gel column.

seen in Fig. 5. The enzyme was judged to be homogeneous, its $\mathrm{p} I$ being 4.31 .

\section{Amino acid composition}

A $10 \mathrm{mg}$ sample of the purified enzyme preparation, dried at $80^{\circ} \mathrm{C}$ under reduced pressure over phosphorus pentoxide, was hydrolyzed with $6 \mathrm{~N}$ redistilled $\mathrm{HCl}$ in a sealed tube at $110^{\circ} \mathrm{C}$ for $24 \mathrm{hr}$. The hydrolyzate was evapor: ted to dryness to remove $\mathrm{HCl}$ and then analyze $\mathbb{A}$ with an automatic amino acid analyzer. Tryptophan was analyzed by HPLC. The data are summarized in Table II. The enzyme is rich in alanine and glycine, but poor in lysine and methionine. Both histidine and tryptophan were found in small amounts. Cystine (half) 'vas not detected, even with performic

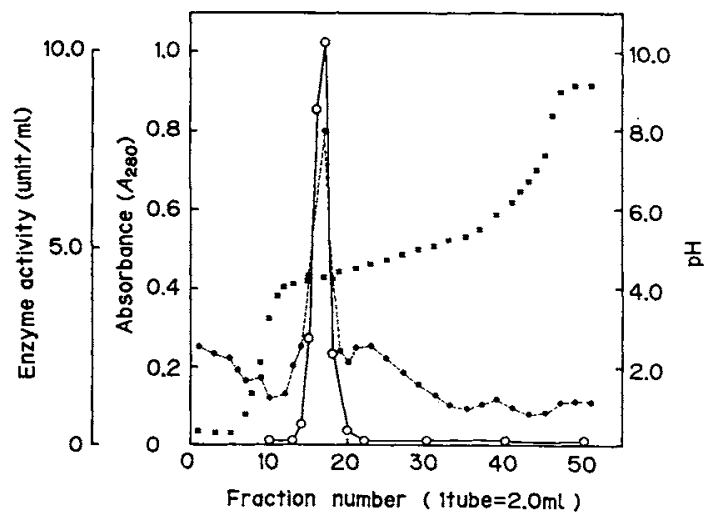

FIG. 5. Isoelectric Focusing of the Purified Glucodextranase.

The purified enzyme, $3.9 \mathrm{mg}$ of protein and 99.8 units of enzyme activity, was applied to a $110 \mathrm{ml} \mathrm{LKB}$ column. After electrophoresis at $4^{\circ} \mathrm{C}$ for $50 \mathrm{hr}$ at a constant voltage of $1,100 \mathrm{~V}$, fractions of $2 \mathrm{ml}$ were collected, and then the enzyme activity, protein concentration and $\mathrm{pH}$ of each fraction were assayed.

-----, protein concentration $\left(A_{280 \mathrm{~nm}}\right) ;-\bigcirc-$, glucodextranase activity; $\mathbf{\square}, \mathrm{pH}$.

TABle II. Amino Acid Composition of the Purified Enzyme

\begin{tabular}{lc}
\hline Amino acid & Molar ratio $(\%)$ \\
\hline Arginine & 4.47 \\
Lysine & 2.88 \\
Histidine & 1.33 \\
Phenylalanine & 2.24 \\
Tyrosine & 4.28 \\
Leucine & 7.38 \\
Isoleucine & 2.32 \\
Methionine & 1.21 \\
Valine & 7.02 \\
Alanine & 14.56 \\
Glycine & 12.51 \\
Proline & 5.56 \\
Glutamic acid & 8.22 \\
Serine & 5.65 \\
Threonine & 8.77 \\
Aspartic acid & 9.42 \\
Tryptophan & 2.18 \\
Cystine (half) & ${ }^{a}$
\end{tabular}

a Measured by the performic acid oxidation method. ${ }^{12)}$

acid oxidation. ${ }^{12)}$

Effect of $p H$ on the activity of the enzyme

The effect of $\mathrm{pH}$ on the activity of the purified 
enzyme was studied under the standard assay conditions at $30^{\circ} \mathrm{C}$ for 6 min using $50 \mathrm{~mm} \beta, \beta^{\prime}-$ dimethylglutaric acid- $\mathrm{NaOH}$ buffer containing $5 \mathrm{~mm}$ calcium chloride, $\mathrm{pH} 4.0 \sim 7.0$. The enzyme showed a single maximum at $\mathrm{pH}$ 6.0.

\section{Stabilities of the enzyme toward $p H$ and temperature}

Two series of enzyme solutions were prepared, the solutions containing equal amounts $(0.01 \mathrm{ml})$ of the purified enzyme (0.48 units) and individually adjusted to a $\mathrm{pH}$ from 3.5 to 7.5 by adding $0.59 \mathrm{ml}$ of $50 \mathrm{~mm} \beta, \beta^{\prime}$-dimethylglutaric acid- $\mathrm{NaOH}$ buffer containing $5 \mathrm{~mm}$

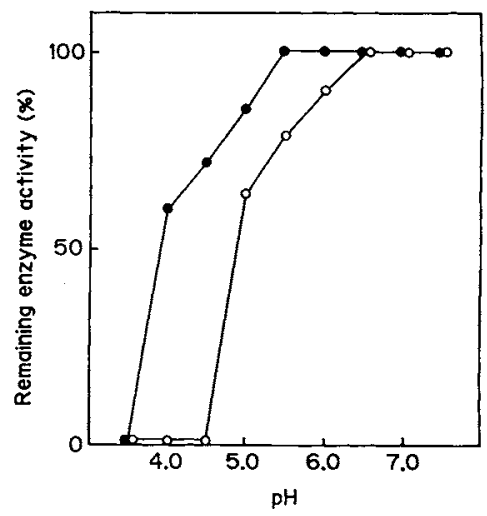

Fig. 6. Stabilities of the Purified Glucodextranase with Respect to $\mathrm{pH}$ and Temperature.

- - held at $4^{\circ} \mathrm{C}$ for $24 \mathrm{hr}$ before assaying for enzyme activity; $-\mathrm{O}-$, held at $45^{\circ} \mathrm{C}$ for $2 \mathrm{hr}$ before assaying for enzyme activity. The experimental details are given in the text.

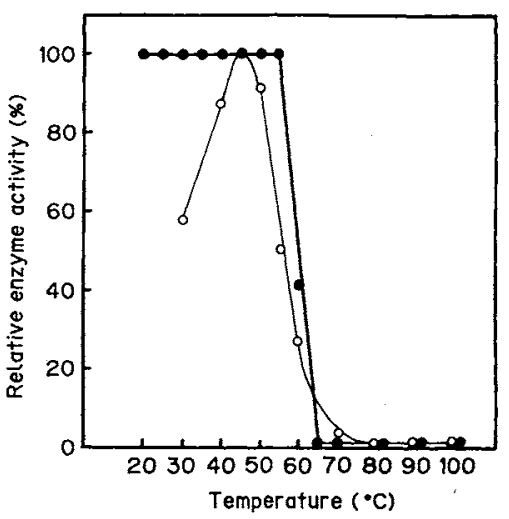

FIG. 7. Effects of Temperature on the Stability (- and Activity ( $-\mathrm{O}-$ ) of the Purified Glucodextranase.

The experimental details are given in the text. calcium chloride. After one set of solutions had been kept at $4^{\circ} \mathrm{C}$ for $24 \mathrm{hr}$ and the other set at $45^{\circ} \mathrm{C}$ for $2 \mathrm{hr}$, both sets of buffered enzyme solutions were diluted 5 -fold with the same buffer (pH 6.0) as described above. Each $0.25 \mathrm{ml}$ sample (0.04 units) was examined for the remaining glucodextranase activity by means of the standard assay at $30^{\circ} \mathrm{C}$ for $10 \mathrm{~min}$. The results are shown in Fig. 6. The enzyme was completely stable over the $\mathrm{pH}$ range of $5.5 \sim 7.5$ at $4^{\circ} \mathrm{C}$ and that of $6.5 \sim 7.5$ at $45^{\circ} \mathrm{C}$, under the conditions used.

Purified enzyme solutions (5.40 units) in $0.2 \mathrm{ml}$ of $20 \mathrm{~mm}$ acetate buffer ( $\mathrm{pH} 6.0$ ) containing $5 \mathrm{~mm}$ calcium acetate were heated at various temperatures for $10 \mathrm{~min}$ and then cooled immediately in an ice-bath. After heat treatment, the enzyme solutions were diluted 170-fold with the same buffer as mentioned above. The remaining glucodextranase activity was then measured with $0.25 \mathrm{ml}$ of each enzyme solution ( 0.04 units) by means of the standard assay at $30^{\circ} \mathrm{C}$ for $10 \mathrm{~min}$. The results (Fig. 7) indicate that the enzyme is completely stable at temperatures below $55^{\circ} \mathrm{C}$. The enzyme retained about $40 \%$ of its original activity on heating at $60^{\circ} \mathrm{C}$, but was completely inactivated on heating at $65^{\circ} \mathrm{C}$ under the conditions used.

\section{Effect of temperature on the activity of the enzyme}

Enzyme solutions ( 0.034 units) in $1.0 \mathrm{ml}$ of $40 \mathrm{~mm}$ acetate buffer ( $\mathrm{pH} 6.0$ ) containing $10 \mathrm{~mm}$ calcium acetate were incubated with $1.0 \mathrm{ml}$ of a $0.5 \%$ dextran T2000 solution at different reaction temperatures for $10 \mathrm{~min}$. The glucodextranase activity per $1.0 \mathrm{ml}$ of each reaction mixture was assayed. The optimum temperature of the activity of the enzyme was $45^{\circ} \mathrm{C}$, as shown in Fig. 7.

\section{Effects of various metal ions and several enzyme inhibitors on the activity of the enzyme}

The enzyme was incubated with an equal volume of a metal ion or inhibitor solution $(10 \mathrm{~mm}, \mathrm{pH} 6.0)$ at $30^{\circ} \mathrm{C}$ for $30 \mathrm{~min}$ and then cooled immediately in an ice-bath. Then the 


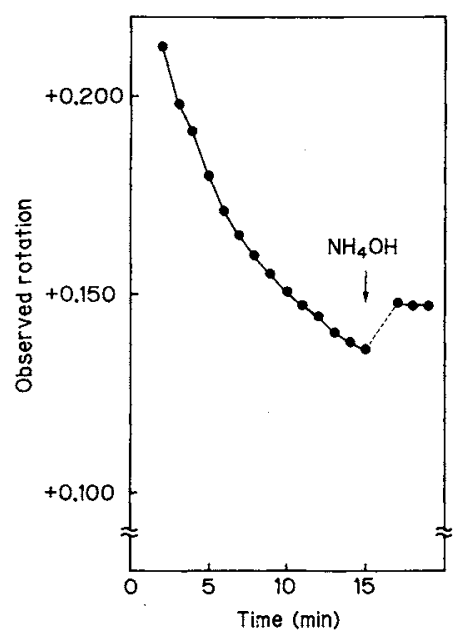

FIG. 8. Changes in Optical Rotation during the Hydrolysis of Isomaltose by the Purified Glucodextranase and after Base-catalyzed Mutarotation.

A drop of concentrated ammonium hydroxide was added to the digest at the time indicated by an arrow and then the optical rotation was followed until $19 \mathrm{~min}$ incubation. The experimental details are given in the text.

mixtures were diluted 20 -fold with $20 \mathrm{~mm}$ acetate buffer ( $\mathrm{pH} \mathrm{6.0)}$ ) and the remaining activity per $\mathrm{ml}$ of each reaction mixture containing 0.020 units of enzyme was examined by means of the standard assay at $30^{\circ} \mathrm{C}$ for $20 \mathrm{~min}$. Inactivation of the enzyme was partial with $5 \mathrm{mM} \mathrm{Pb}^{2+}$ or $\mathrm{Zn}^{2+}$, being about $20 \%$ inhibition in each case. On the other hand, $5 \mathrm{~mm}$ each of $\mathrm{Cu}^{2+}, \mathrm{Hg}^{2+}, \mathrm{Fe}^{3+}, \mathrm{KMnO}_{4}$ and NBS inactivated the enzyme completely. EDTA, $p C M B$ and other metal ions tested had no inhibitory effect on the activity of the enzyme.

Anomeric configurations of hydrolysis products

The anomeric configurations of the reaction products formed by the enzyme were examined. The optical rotation of isomaltose decreased gradually in a negative direction after addition of the enzyme. However, an immediate upward mutarotation was observed upon the addition of ammonium hydroxide to the reaction mixture (Fig. 8). This result indicates, at least qualitatively, that the enzyme releases $\beta$-glucose, and that the $\alpha$-glycosidic linkages of the substrates are inverted.

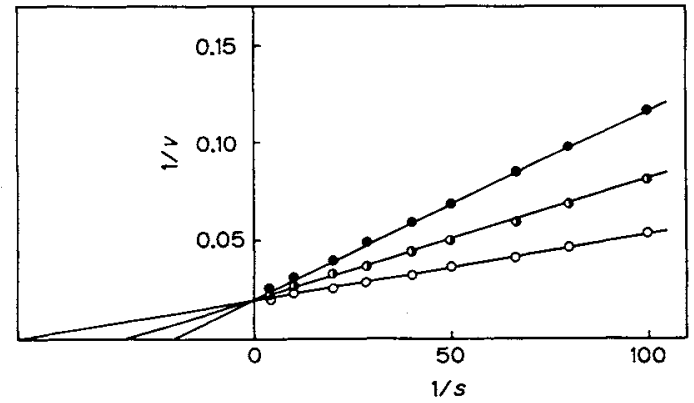

FIG. 9. Lineweaver-Burk Plots for the Purified Glucodextranase.

- - -, glucodextranase activity toward dextran in the absence of $5 \mathrm{~mm}$ phenyl $\alpha$-D-glucoside or $10 \mathrm{~mm}$ methyl $\alpha$ D-glucoside; - - , glucodextranase activity toward dextran in the presence of $5 \mathrm{~mm}$ phenyl $\alpha$-D-glucoside; - - glucodextranase activity toward dextran in the presence of $10 \mathrm{~mm}$ methyl $\alpha$-D-glucoside. $s$, dextran concentration $(\%) ; v$, initial velocity $(\mu \mathrm{mol}$ glucose $/ \mathrm{min} / \mathrm{mg}$ protein). The experimental details are given in the text.

\section{Inhibition kinetics}

The Lineweaver-Burk plots of glucodextranase activity toward dextran $T 2000$ in the presence or absence of $5 \mathrm{~mm}$ phenyl $\alpha$-Dglucoside or $10 \mathrm{~mm}$ methyl $\alpha$-D-glucoside are shown in Fig. 9. The $K m$ and $k_{0}$ values of the enzyme for dextran were $0.014 \%$ and $95.24 \mathrm{sec}^{-1}$, respectively. As can be seen in Fig. 9 , both phenyl $\alpha$-D-glucoside and methyl $\alpha$-Dglucoside are typical competitive inhibitors for the enzyme. The $K i$ values of the enzyme for phenyl $\alpha$-D-glucoside and methyl $\alpha$-D-glucoside were calculated to be 1.69 and $8.28 \mathrm{~mm}$, respectively.

\section{DISCUSSION}

The first aim of this study was to establish a simpler and more effective enzyme purification procedure than the previous one. ${ }^{1)}$ A glucodextranase was simply purified from cell-free culture broth of $A$. globiformis $\mathrm{I} 42$ by ammonium sulfate fractionation, affinity chromatography on Sephadex G-100 and column chromatography on DEAE-cellulose. It is remarkable that the activity recovery of the enzyme at the final purification stage $(67.8 \%$, Table I) is about 7 times higher than the 
previous one $(10 \%)^{1)}$ The purified enzyme showed a specific acitivity of 25.6 units $/ \mathrm{mg}$ protein and was judged to be essentially homogeneous on PAGE and SDS-PAGE as well as isoelectric focusing. The specific activity of this enzyme preparation is considerably higher than that of the previous one ${ }^{1)}$ (18.0 units/mg protein). Using the purified enzyme, we obtained new data as to the physicochemical and enzymatic properties of the enzyme, which were lacking in the previous reports. ${ }^{1 \sim 3)}$

The molecular weight of the purified enzyme (MW 120,000) is close to those of both the purified dextran $\alpha-1,2$ debranching enzyme (MW 125,000) $)^{13)}$ and isomaltotriose-producing dextranase II (MW 114,000) ${ }^{14)}$ from Flavobacterium sp. M-73, however, it is quite different from that of the purified isomaltodextranase (MW 69,000) from A. globiformis T6. ${ }^{15)}$ Both endodextranases CD-I and -II from Chaetomium gracile contain a sugar moiety (4.5\% each). ${ }^{16)}$ However, no carbohydrate moiety seemed to be associated with the purified glucodextranase from A. globiformis I42, as is the case of the purified isomaltodextranase from $A$. globiformis T6. ${ }^{15}$ )

The amino acid composition of the purified glucodextranase was somewhat different from those of the two endodextranases of $C$. gracile. ${ }^{16)}$ The most striking discrepancy is that both the $C$. gracile enzymes have cystine (half) residues, while the purified enzyme does not. Another interesting point is that the alanine content of the purified enzyme is much higher than those of the $C$. gracile enzymes. These results resemble well the case of the purified isomalto-dextranase from $A$. globiformis T6. ${ }^{15}$

On the basis of the observed mutarotation upon hydrolysis of isomaltose by the purified enzyme (Fig. 8), we concluded that the anomeric carbon atoms of the reaction products were of the $\beta$-configuration. This supports the finding of Ohya et al. ${ }^{2)}$ Using a gas-liquid chromatographic method, we also confirmed that the purified enzyme released only $\beta$-glucose from substrates, inverting the original $\alpha$ anomeric configuration. ${ }^{17)}$

Acknowledgments. The authors wish to express their gratitude to Meito Sangyo Co., Ltd. for the generous gift of clinical dextran (Meito 70) and also to Bio Science Laboratories, Meiji Seika Kaisha, Ltd. for the amino acid analysis.

\section{REFERENCES}

1) T. Sawai, T. Yamaki and T. Ohya, Agric. Biol. Chem., 40, 1293 (1976).

2) T. Ohya, T. Sawai, S. Uemura and K. Abe, Agric. Biol. Chem., 42, 571 (1978).

3) T. Ohya, H. Suzuki and T. Sawai, Agric. Biol. Chem., 44, 203 (1980).

4) N. M. Papadopoulas and W. C. Hess, Arch. Biochem. Biophys., 88, 167 (1960).

5) A. Dahlquist, Biochem. J., 80, 547 (1961).

6) O. H. Lowry, N. J. Rosebrough, A. L. Farr and R. J. Randall, J. Biol. Chem., 193, 265 (1951).

7) M. Dubois, K. A. Gilles, J. K. Hamilton, P. A. Rebers and F. Smith, Anal. Chem., 28, 350 (1956).

8) B. J. Davis, Ann. N.Y. Acad. Sci, 121, 404 (1964).

9) K. Weber and M. Osborn, J. Biol. Chem., 244, 4406 (1969).

10) O. Vesterberg and H. Svensson, Acta Chem. Scand., 20, 820 (1966).

11) H. Lineweaver and D. Burk, J. Am. Chem. Soc, 56, 658 (1984)

12) S. Moore, J. Biol. Chem., 238, 235 (1963).

13) Y. Mitsuishi, M. Kobayashi and K. Matsuda, Agric. Biol. Chem., 43, 2283 (1979).

14) M. Kobayashi, S. Takagi, M. Shiota, Y. Mitsuishi and K. Matsuda, Agric. Biol. Chern., 47, 2585 (1983).

15) G. Okada, T. Takayanagi and T. Sawai, Agric. Biol. Chem., 52, 495 (1988).

16) A. Hattori, K. Ishibashi and S. Minato, Agric. Biol. Chem., 45, 2409 (1981).

17) T. Takayanagi, G. Okada and S. Chiba, Agric. Biol. Chem., 51, 2337 (1987). 